\title{
Response Surface Optimization of Extraction Conditions and In Vitro Antioxidant and Antidiabetic Evaluation of an Under-Valued Medicinal Weed, Mimosa pudica
}

\author{
Nor Saffana Baharuddin 1(D, Muhamad Aidilfitri Mohamad Roslan ${ }^{1}$ (D), Mohsen Ahmed Mohammed Bawzer ${ }^{1}$, \\ Azzreena Mohamad Azzeme ${ }^{2}$ (D), Zuraida Ab Rahman ${ }^{3}$, Mohd Ezuan Khayat 2,4 (D), Nor Aini Abdul Rahman 1,4 \\ and Zulfazli M. Sobri $1,4, *$ (D)
}

Citation: Baharuddin, N.S.; Roslan, M.A.M.; Bawzer, M.A.M.; Mohamad Azzeme, A.; Rahman, Z.A.; Khayat, M.E.; Rahman, N.A.A.; Sobri, Z.M. Response Surface Optimization of Extraction Conditions and In Vitro Antioxidant and Antidiabetic Evaluation of an Under-Valued Medicinal Weed, Mimosa pudica. Plants 2021, 10, 1692. https:// doi.org/10.3390/plants10081692

Academic Editor: Stefania Lamponi

Received: 1 July 2021

Accepted: 16 July 2021

Published: 18 August 2021

Publisher's Note: MDPI stays neutral with regard to jurisdictional claims in published maps and institutional affiliations.

Copyright: (c) 2021 by the authors Licensee MDPI, Basel, Switzerland. This article is an open access article distributed under the terms and conditions of the Creative Commons Attribution (CC BY) license (https:// creativecommons.org/licenses/by/ $4.0 /)$.
1 Department of Bioprocess Technology, Faculty of Biotechnology and Biomolecular Sciences, Universiti Putra Malaysia, Serdang 43400, Selangor, Malaysia; nsaffana@gmail.com (N.S.B.); fitree91@gmail.com (M.A.M.R.); mohsenbaw2@gmail.com (M.A.M.B.); nor_aini@upm.edu.my (N.A.A.R.)

2 Department of Biochemistry, Faculty of Biotechnology and Biomolecular Sciences, Universiti Putra Malaysia Serdang 43400, Selangor, Malaysia; azzreena@upm.edu.my (A.M.A.); m_ezuan@upm.edu.my (M.E.K.)

3 Biotechnology Research Centre, MARDI Headquarters, Persiaran MARDI-UPM, Serdang 43400, Selangor, Malaysia; azuraida@mardi.gov.my

4 Bioprocessing and Biomanufacturing Research Centre, Faculty of Biotechnology and Biomolecular Sciences, Universiti Putra Malaysia, Serdang 43400, Selangor, Malaysia

* Correspondence: zulfazli@upm.edu.my

Abstract: Mimosa pudica Linn is a well-known perennial herb and is traditionally used in ayurvedic medicine for the treatment of various illnesses. Despite its abundance in nature, the therapeutic potential of this invasive weed is deemed to be underappreciated in Malaysia. Previous studies have found an abundance of bioactive compounds associated with potent antioxidant properties in all parts of the plant. However, the optimum parameters required for the extraction of antioxidant compounds are still unknown. Therefore, the present study aimed to optimize the solvent extraction parameters of M. pudica using response surface methodology to enrich the accumulation of antioxidant compounds in the extracts. The effects of the optimized M. pudica extracts were then evaluated on the cell viability and glucose uptake ability in a 3T3-L1 adipocyte cell line. The highest total phenolic (91.98 mg of gallic acid equivalent per $g$ of the dry extract) and total flavonoid content (606.31 mg of quercetin equivalent per $g$ of the dry extract) were recorded when using $100 \%$ ethanol that was five-fold and three-fold higher, respectively, as compared to using 50\% ethanol. The extract concentration required to achieve $50 \%$ of antioxidant activity ( $\mathrm{IC}_{50}$ value) was $42.0 \mu \mathrm{g} / \mathrm{mL}$ using $100 \%$ ethanol as compared to $975.03 \mu \mathrm{g} / \mathrm{mL}$ using $50 \%$ ethanol. The results indicated that the use of $100 \%$ ethanol solvent had the greatest impact on the accumulation of antioxidant compounds in the extract $(p<0.05)$. Cell viability assay revealed that all extract concentration treatments recorded a viability level of above $50 \%$. Glucose uptake assay using 2-NBDG analog showed that the cells treated with $50 \mu \mathrm{g} / \mathrm{mL}$ extract combined with insulin were five-fold higher than the control group. Given the high antioxidant and antidiabetic properties of this plant, M. pudica can be easily highlighted as a plant subject of interest, which warrants further investigation for nutraceutical prospects.

Keywords: Mimosa pudica; antioxidant; antidiabetic; 3T3-L1; response surface methodology

\section{Introduction}

Mimosa pudica Linn. is a perennial herb species that belongs to the family of Fabaceae. It is commonly known as sensitive plant or shy plant and recognized for its shrinking reaction to contact as a defense mechanism. The whole parts of the plant are incorporated as medicine in the Ayurveda, Indian traditional medicine system. Due to its therapeutic values, it has been used in ethnomedicine for centuries in treating various 
diseases, such as diabetes, fever, wounds, ulcers, and dyspepsia [1]. This creeping perennial shrub is originated from tropical climate regions like Southeast Asia and can be easily found on roadsides, walkways, croplands, and home gardens in countries like Malaysia, India, China, Bangladesh, Philippines, etc. This plant species is easily dismissed as weeds owing to its invasive behavior, which causes inconveniences in home gardens and cropland maintenance.

Previous phytochemical investigations on M. pudica have resulted in the identification of at least 40 well-known chemical constituents from the group of alkaloids, phenols, and flavonoids. Through high-performance liquid chromatography (HPLC), gas chromatography-mass spectrometry (GC-MS), and liquid chromatography-mass spectrometry (LC-MS) techniques, high profusion bioactive compounds of M. pudica have been detected with a good range of recovery and detection limit [2-5]. Recent phytochemical profiling of M. pudica by Ahuchaogu et al. [6] revealed the presence of flavonoids C-glycosides, sterols, terpenoids, tannins, fatty acids, ascorbic acid, crocetin, D-glucuronic acid, linoleic acid, palmitic acid, stearic acid, mimosine, D-xylose, and $\beta$-sitosterols. Several secondary metabolites of M. pudica have been successfully isolated, which include bufadienolide, D-pinitol, norepinephrine, P-coumaric acid, mimopudine, and mimosine. Additionally, its crude extracts and isolates have been reported to exhibit a broad spectrum of in vitro and in vivo pharmacological activities, including antidiabetic, antimicrobial, wound healing, antidepressant, and ethnoveterinary potential, among others [7]. Despite its abundance and wide-ranging medicinal properties, it is deemed to be underappreciated and perceived as an undesirable plant.

Diabetes mellitus is a chronic metabolic disease marked by hyperglycemia, or elevated blood glucose levels, caused by insulin deficiency (type 1 diabetes) or by insulin resistance (type 2 diabetes) [8-10]. Global statistics have recorded that 463 million individuals worldwide were diagnosed with diabetes within the year 2018 to 2019, where 3.6 million among them were Malaysians [11]. The most prevalent kind of diabetes is type 2 diabetes mellitus, which is characterized by the imbalance between insulin production and blood sugar absorption, resulting in a greater risk of both acute and long-term complications, as well as mortality at a younger age. Since type 2 diabetes is considered avoidable and treatable, many researchers have been focusing on its management and alternative treatments [11].

A substantial amount of data suggests that hyperglycemia is the primary cause of oxidative stress, which is linked to a fundamental step in the onset and progression of diabetes problems $[12,13]$. This highlights the correlation between oxidative stress and diabetes, even though the exact processes by which oxidative stress increases the development of diabetes complications are only partially understood [14,15]. Hyperglycemia-induced oxidative stress, which results in the creation of free radical species, stimulates the synthesis of inflammatory mediators [16]. Free radicals are unstable kinds of molecules that target healthy cells to couple up their odd free electrons, which results in cellular dysfunction [17]. The occurrence of reactive oxygen species (ROS) has been linked to various diseases or disorders like cancers, diabetes, hyperuricemia, gout, and inflammatory diseases [18]. ROS or free radicals found in the human biological systems can damage various molecules, such as DNA, and eventually inhibit cell functions. Antioxidants are a class of chemical compounds that actively or indirectly decrease free radicals and prevent oxidation. Plantbased antioxidants are free radical scavenging agents that can reduce the harmful effects of unstable species on the human body and may be effective in the treatment of diabetic problems [19].

Exogenous supplementation of antioxidants can relieve oxidative stress in the body. However, some synthetic antioxidants have demonstrated possible harmful effects, such as liver damage and carcinogenesis, in the long term [20-22]. Academics and pharmaceutical institutions have been racing in a search for novel secondary metabolites in plants, with the hope of discovering new approaches in the treatments of diseases [23]. 
The most common conventional optimization techniques include the one-factor-at-atime (OFAT) or the single-factor experiment techniques. OFAT is considered a laborious and cost-inefficient approach since a multitude of runs of experiments is required to achieve a consensus. Conversely, response surface methodology (RSM) is a powerful multivariable optimization technique, which is generally easier and more statistically robust [24]. This tool describes the interactional effects between a set of data and can be used to generate models for the prediction of the responses [25]. Previous RSM-based optimization of M. pudica extraction methods used methanol as the sole solvent while incorporating microwave-assisted extraction to obtain maximum antioxidative compounds [26]. A1though the results seemed promising, other solvents, such as ethanol, have yet to be tuned using the same optimization method.

In light of the potentially high nutraceutical values of $M$. pudica, the present study aimed to optimize the extraction conditions of $M$. pudica to enrich the accumulation of antioxidant compounds through the Box-Behnken Design of RSM, and thus evaluate the antioxidant and antidiabetic potential of the optimized crude extract.

\section{Materials and Methods}

\subsection{Box-Behnken Design}

The Box-Behnken design (BBD) was used to obtain the experimental design, analysis of results, and regression models. An experimental design using BBD was established using three factors (extraction time, temperature, ethanol concentration) with three levels (30-90 $\mathrm{min}, 40-80{ }^{\circ} \mathrm{C}, 50-100 \%$ ethanol) according to the range of parameters described in previous reports [27-29]. The effects of extraction time (A), water bath temperature (B), and ethanol concentration (diluted with water) (C) on the response, i.e., crude extract yield, $\mathrm{IC}_{50}$ value, total phenolic content (TPC), and total flavonoid content (TFC), were investigated to determine the optimal extraction parameters. The entire design consisted of 17 experimental runs, which were carried out in a random sequence.

\subsection{Preparation of Plant Extracts}

The air-dried aerial parts of M. pudica were purchased from a local farmer in Changloon, Kedah. The sample was pulverized using a commercial blender (PB-3202L, Panasonic, China), sieved, and stored in a sealed container at room temperature for future use. The extracts were prepared following [30] with minor modifications. Solvent extraction was conducted by mixing $10 \mathrm{~g}$ of the powdered sample with $50 \mathrm{~mL}$ of ethanol (Avantor, Radnor, PA, USA) of varying concentrations (50\%, 75\%, and 100\%), and left at different extraction times and temperature levels in a water bath (WB-11, WiseBath, Brighton, CO, USA). The solvent from primary extracts was evaporated under a reduced pressure using a rotary evaporator (Rotary Evaporator N-1000, Eyela Oilbath OSB-2000, and Eyela N-1000 Aspirator, Tokyo, Japan) and the resulting filtrate was diluted to $2 \mathrm{mg} / \mathrm{mL}$ in absolute ethanol to yield a stock solution. The stock solution was further diluted to between 0.05 and $1.00 \mathrm{mg} / \mathrm{mL}$ as the working sample solution. The extraction yield was calculated using the following Equation (1) by [31]:

$$
\mathrm{Y}=\mathrm{Wd} / \mathrm{Ve} \times \mathrm{Rss} \times 100
$$

where $\mathrm{Wd}$ is the weight of dried extract $(\mathrm{g})$, Ve is the volume of aqueous filtered $(\mathrm{mL})$, and Rss is the ratio of solvent to solid $(\mathrm{mL} / \mathrm{g})$.

\subsection{Determination of DPPH Radical Scavenging Assay}

The antioxidant activity of the extracts against DPPH radicals was evaluated according to the method previously described by Patro et al. [32] with slight modifications. Exactly $0.5 \mathrm{~mL}$ of each sample with a concentration between 0.05 and $1.00 \mathrm{mg} / \mathrm{mL}$ were mixed with $1.0 \mathrm{~mL}$ of $0.1 \mathrm{mM}$ DPPH reagent (Sigma Aldrich, St. Louis, MO, USA). The reaction mixture was incubated in the dark at room temperature for $30 \mathrm{~min}$. The absorbance of the reaction was then recorded at $517 \mathrm{~nm}$ using a UV-visible spectrophotometer (SQ2800, 
Unico, Dayton, NJ, USA). The antioxidant efficacy of all samples was compared to ascorbic acid at $25-200 \mu \mathrm{g} / \mathrm{mL}$ (Loba Chemie, Mumbai, India) as a positive control in triplicate using the following Equation (2):

$$
\text { DPPH radical scavenging activity }(\%)=[(\mathrm{C}-\mathrm{S}) / \mathrm{C}] \times 100
$$

where $\mathrm{C}$ is the absorbance value of the control and $\mathrm{S}$ is the absorbance value of the sample.

\subsection{Determination of Total Phenolic Content (TPC)}

The TPC of the extracts was measured according to the method reported by Ibrahim et al. [33] with slight modifications. Briefly, samples of $0.1 \mathrm{mg} / \mathrm{mL}$ were mixed with $1.0 \mathrm{~mL}$ of Folin-Ciocalteu reagent (Sigma Aldrich, St. Louis, MO, USA) and shaken for $5 \mathrm{~min}$ before $10 \mathrm{~mL}$ of $7 \% \mathrm{Na}_{2} \mathrm{CO}_{3}$ (Himedia Labs, Mumbai, India) was added. The mixture solutions were adjusted with ethanol to a volume of $25 \mathrm{~mL}$, mixed thoroughly, and incubated at ambient temperature in dark conditions. After $90 \mathrm{~min}$, the absorbance was measured at $750 \mathrm{~nm}$. The TPC was expressed as milligrams of gallic acid (Sigma Aldrich, St. Louis, MO, USA) equivalent per gram of extract (mg GAE/g extract) using the calibration curve equation: $y=0.0066 x+0.0379, R^{2}=0.9975$, at concentrations between 50 and $500 \mathrm{mg} / \mathrm{L}$.

\subsection{Determination of Total Flavonoid Content (TFC)}

The TFC of the extracts was measured as previously described by Chandra et al. [34] with slight modifications. Exactly $500 \mu \mathrm{L}$ of the sample with a concentration of $1 \mathrm{mg} / \mathrm{mL}$ was mixed with $150 \mu \mathrm{L}$ of $5 \% \mathrm{NaNO}_{3}$ (R\&M Chemical, Subang, Selangor) and left for $5 \mathrm{~min}$. Then, $150 \mu \mathrm{L}$ of $10 \% \mathrm{Al}_{2} \mathrm{Cl}_{3}$ (R\&M Chemical, Subang, Selangor) was added into the mixture and left for $6 \mathrm{~min}$. About $1.0 \mathrm{~mL}$ of $1.0 \mathrm{M} \mathrm{NaOH}$ (R\&M Chemical, Subang, Selangor) was added and the mixture was vortexed. The absorbance was measured at $510 \mathrm{~nm}$. TFC was calculated using the calibration curve of quercetin (Sigma Aldrich, USA) equation: $y=0.0008 x+0.1909, R^{2}=0.9793$, at concentrations between 20 and $200 \mu \mathrm{g} / \mathrm{mL}$ and expressed as $\mathrm{mg}$ of quercetin equivalent per $\mathrm{g}$ of extract (mg QE/g extract).

\subsection{Cell Passaging and Maintenance}

Complete growth media (CGM) was prepared by combining $89 \%$ Dulbecco's Modified Eagle's medium (DMEM) (Nacalai Tesque, Kyoto, Japan) high glucose with $10 \%$ fetal bovine serum (FBS) (Nacalai Tesque, Kyoto, Japan) and 1\% penicillin-streptomycin (Nacalai Tesque, Kyoto, Japan). The 3T3-L1 cell line was obtained from American Type Culture Collection (ATCC, Manassas, VA, USA). The cell line was routinely trypsinized into a fresh CGM when it reached $70-80 \%$ confluency. The media was removed from the flask using a $5 \mathrm{~mL}$ serological pipette. The cells left in the flask were washed with $5 \mathrm{~mL}$ Dulbecco's Phosphate Buffered Saline (D-PBS) (Sigma Aldrich, St. Louis, MO, USA). Exactly $2 \mathrm{~mL}$ of trypsin (Nacalai Tesque, Kyoto, Japan) was added to detach the cells from the flask wall. The culture was incubated for $5 \mathrm{~min}$ to let the trypsin act. The flask was then tapped gently and observed under a microscope (Primostar 3, Zeiss, Germany) to ensure cell detachment. About $4 \mathrm{~mL}$ of CGM were added to neutralize the trypsin. The cells were dislodged from the walls gently a few times. The mixture was transferred into a new $15 \mathrm{~mL}$ falcon tube. An appropriate volume of culture media was calculated to culture the cells. A sufficient volume of media was added and seeded into a new culture flask of approximately $6 \times 10^{5}-7 \times 10^{5}$ cells per flask. The cells were spread evenly and incubated at $37^{\circ} \mathrm{C}$ with $5 \% \mathrm{CO}_{2}$ in a humidified incubator and maintained in a sub-confluent state until further use.

\subsection{Cell Viability Assay (MTT Assay)}

Cell viability was determined by the 3-(4,5-dimethylthiazol-2-yl)-2,5-diphenylte trazolium bromide (MTT) (Sigma Aldrich, St. Louis, MO, USA) assay as described by [10]. Cells at $80 \%$ of confluency were seeded into a 96-well clear plate and incubated for $48 \mathrm{~h}$. Then, the cells were treated with extract compounds in serial dilution ranging from $50-800 \mu \mathrm{g} / \mathrm{mL}$ in triplicate following incubation for another $48 \mathrm{~h}$. The media were aspi- 
rated, and the wells were washed with $100 \mu \mathrm{L}$ of D-PBS. Subsequently, $100 \mu \mathrm{L}$ of DMEM without glucose were added along with $100 \mu \mathrm{L}$ of $0.5 \mathrm{mg} / \mathrm{mL}$ MTT reagent followed by a 4-h incubation. The violet-formazan crystals were dissolved in $100 \mu \mathrm{L}$ of dimethyl sulfoxide (DMSO) (Nacalai Tesque, Kyoto, Japan). The absorbance was measured at $570 \mathrm{~nm}$ using a microplate reader (MR9600, Accuris, Sayreville, NJ, USA) and the percentage viability of the cells was calculated using the following formula (3):

$$
\% \text { viable cells }=[(\text { abs sample }- \text { abs blank }) /(\text { abs control }- \text { abs blank })] \times 100
$$

\subsection{Differentiation of 3T3-L1 Cells into Mature Adipocytes}

Differentiation was induced by seeding cells at $70-80 \%$ confluency into a 96 -well black with clear-bottom plate (Greiner Bio-One, Frickenhausen, Germany) and grown to confluence to initiate the growth arrest phase. Then, the media were changed to induction media containing DMEM high glucose supplemented with an adipogenic cocktail $(2.5 \mu \mathrm{L}$ insulin, $1 \mu \mathrm{L}$ DEXA, $10 \mu \mathrm{L}$ IBMX for every mL of DMEM) (Nacalai Tesque, Kyoto, Japan). After two days, the media were replaced with DMEM high glucose supplemented with insulin only. Subsequently, the media were changed every $48 \mathrm{~h}$ with fresh CGM. After 7-10 days, fully differentiated adipocytes were obtained.

\subsection{Glucose Uptake Assay}

The differentiated adipocytes were cultured with glucose-free DMEM. Following $3 \mathrm{~h}$ of incubation, the media were aspirated and rinsed with $100 \mu \mathrm{L}$ of $1.0 \mathrm{M} \mathrm{KRPH}$ buffer $(20 \mathrm{mM}$ HEPES, $137 \mathrm{mM} \mathrm{NaCl}, 4.7 \mathrm{mM} \mathrm{KCl}, 1.2 \mathrm{mM} \mathrm{MgSO}_{4}, 1.2 \mathrm{mM} \mathrm{KH}_{2} \mathrm{PO}_{4}, 2.5 \mathrm{mM} \mathrm{CaCl}_{2}$, and $2 \mathrm{mM}$ pyruvate; $\mathrm{pH}$ 7.4). Then, the cells were treated with $100 \mu \mathrm{L}$ of blank, control, and experimental compounds at the indicated concentrations followed by $10 \mathrm{~min}$ of incubation. Exactly $100 \mu \mathrm{L}$ of $150 \mu \mathrm{g} / \mathrm{mL}$ 2-NBDG (Cayman Chemical, Ann Arbor, MI, USA) were added to each well and incubated for another $30 \mathrm{~min}$. The plate was centrifuged for $5 \mathrm{~min}$ at $400 \times g$ at room temperature and the supernatant was aspirated. Then, $200 \mu \mathrm{L}$ of cell-based assay buffer were added to each well. Extra care was applied to not disturb the cell layer. The plate was centrifuged again, the supernatant was removed, and $100 \mu \mathrm{L}$ of cell-based assay buffer were added to each well. The cells were ready for analysis and analyzed immediately. The 2-NBDG taken up by cells was determined at an excitation wavelength of $475 \mathrm{~nm}$ and an emission wavelength of $550 \mathrm{~nm}$ using a multi-mode microplate reader (M5, SpectraMax, San Jose, CA, USA).

\subsection{Statistical Analysis}

The BBD in RSM was performed using Design Expert Software (Version 11.0, StateEase Inc., Minneapolis, MIN, USA). ANOVA was used to summarize the results obtained under all the experimental conditions. The confidence interval of $95 \%$ was set to test the significant effect of the factors and their interaction. The $F$ statistic test was used to evaluate whether the regression model was adequate to describe the observed data. The percentage of variability of the optimization parameter was analyzed by $R$ squared statistics. The optimal extraction conditions were estimated through regression analysis and 3-D response surface plots. A confirmation experimental run was conducted to verify the validity of the statistical experimental strategies. The cell viability (MTT) assay and glucose uptake assay were analyzed by one-way ANOVA, and the Tukey post hoc test was used for the statistical significance declaration. Both were analyzed using SPSS version 23 (IBM, Armonk, NY, USA), where $p<0.05$ was considered significant.

\section{Results and Discussion}

\subsection{Optimization of Extraction Conditions}

The experimental conditions and results are shown in Table 1, and the ANOVA results are exhibited in Table 2. Multiple regressions were used to analyze the data and determine the relative relationship between the test variable and the response variable, which was defined by second-order polynomial Equations (4)-(7), respectively:

Extract yield, $\mathrm{Y}_{1}=16.16+(-0.7875 \mathrm{~A})+0.5125 \mathrm{~B}+(-7.2 \mathrm{C})+1.6 \mathrm{AB}+1.775 \mathrm{AC}+1.575 \mathrm{BC}$

$$
+1.495 \mathrm{~A}^{2}+0.145 \mathrm{~B}^{2}+\left(-4.93 \mathrm{C}^{2}\right)
$$




$$
\begin{aligned}
& \mathrm{IC}_{50} \text { value, } \mathrm{Y}_{2}=126.274+(-42.3637 \mathrm{~A})+126.288 \mathrm{~B}+(-311.681 \mathrm{C})+33.6525 \mathrm{AC}+(-116.5 \mathrm{BC})+180.382 \mathrm{~A}^{2} \\
& +\left(-50.2308 \mathrm{~B}^{2}\right)+172.957 \mathrm{C}^{2} \\
& \text { TPC, } \mathrm{Y}_{3}=57.30+9.39 \mathrm{~A}+0.6700 \mathrm{~B}+28.44 \mathrm{C}+(-6.70 \mathrm{AB})+(-0.2300 \mathrm{AC})+3.27 \mathrm{BC}+\left(-0.6490 \mathrm{~A}^{2}\right) \\
& +2.49 \mathrm{~B}^{2}+\left(-3.17 \mathrm{C}^{2}\right)
\end{aligned}
$$

$\mathrm{TFC}, \mathrm{Y}_{4}=397.89+9.22 \mathrm{~A}-0.9387 \mathrm{~B}+149.22 \mathrm{C}+(-65.47 \mathrm{AB})+(-9.22 \mathrm{AC})+(-49.84 \mathrm{BC})+\left(-61.05 \mathrm{~A}^{2}\right)+62.70 \mathrm{C}^{2}$

\begin{tabular}{|c|c|c|c|c|c|c|c|}
\hline Run & $\begin{array}{c}\text { Extraction } \\
\text { Time (min) }\end{array}$ & $\begin{array}{c}\text { Temperature } \\
\left({ }^{\circ} \mathrm{C}\right)\end{array}$ & $\begin{array}{c}\text { Ethanol } \\
(\%)\end{array}$ & $\begin{array}{c}\text { Extract Yield } \\
(\%)\end{array}$ & $\begin{array}{c}\mathrm{DPPH}\left(\mathrm{IC}_{50},\right. \\
\mu \mathrm{g} / \mathrm{mL})\end{array}$ & $\begin{array}{l}\text { Phenolic Content } \\
\text { (mg GAE/g) }\end{array}$ & $\begin{array}{l}\text { Flavonoid Content } \\
\quad(\mathrm{mg} \mathrm{QE} / \mathrm{g})\end{array}$ \\
\hline & A & B & $C$ & $Y_{1}$ & $Y_{2}$ & $Y_{3}$ & $Y_{4}$ \\
\hline 1 & 30 & 60 & 100 & 4.0 & 72.0 & 76.03 & 606.31 \\
\hline 2 & 30 & 60 & 50 & 25.9 & 975.03 & 14.51 & 209.44 \\
\hline 3 & 60 & 40 & 100 & 5.0 & 42.0 & 85.87 & 660.06 \\
\hline 4 & 30 & 80 & 75 & 17.0 & 424.0 & 62.79 & 415.69 \\
\hline 5 & 60 & 60 & 75 & 13.6 & 106.5 & 42.39 & 260.69 \\
\hline 6 & 60 & 80 & 100 & 7.3 & 45.0 & 80.07 & 476.31 \\
\hline 7 & 90 & 40 & 75 & 15.4 & 73.2 & 68.9 & 385.69 \\
\hline 8 & 60 & 60 & 75 & 23.1 & 283.5 & 59.06 & 436.31 \\
\hline 9 & 60 & 60 & 75 & 13.9 & 58.67 & 65.42 & 400.06 \\
\hline 10 & 90 & 60 & 100 & 3.1 & 51.5 & 91.98 & 574.44 \\
\hline 11 & 60 & 80 & 50 & 14.6 & 689.0 & 20.82 & 357.56 \\
\hline 12 & 60 & 60 & 75 & 16.2 & 82.5 & 69.96 & 490.06 \\
\hline 13 & 60 & 60 & 75 & 14.0 & 100.2 & 49.66 & 408.81 \\
\hline 14 & 30 & 40 & 75 & 17.3 & 170.5 & 34.36 & 204.44 \\
\hline 15 & 90 & 60 & 50 & 17.9 & 819.92 & 31.38 & 214.44 \\
\hline 16 & 90 & 80 & 75 & 21.5 & 358.0 & 70.52 & 335.06 \\
\hline 17 & 60 & 40 & 50 & 18.6 & 220.0 & 39.71 & 341.94 \\
\hline
\end{tabular}

where $\mathrm{A}, \mathrm{B}$, and $\mathrm{C}$ represent the extraction time, temperature, and ethanol concentration, respectively.

\begin{tabular}{|c|c|c|c|c|c|c|c|c|c|}
\hline \multirow[b]{2}{*}{ Sources } & \multirow[b]{2}{*}{ df } & \multicolumn{4}{|c|}{ Extract Yield } & \multicolumn{4}{|c|}{$\mathrm{IC}_{50}$ Value } \\
\hline & & $\begin{array}{l}\text { Sum of } \\
\text { Squares }\end{array}$ & $\begin{array}{l}\text { Mean } \\
\text { Square }\end{array}$ & F-Value & $p$-Value & $\begin{array}{l}\text { Sum of } \\
\text { Squares }\end{array}$ & $\begin{array}{l}\text { Mean } \\
\text { Square }\end{array}$ & F-Value & $p$-Value \\
\hline Model & 9 & 563.34 & 62.59 & 3.67 & 0.0501 & $1.259 \times 10^{6}$ & $1.574 \times 10^{5}$ & 10.22 & 0.0018 \\
\hline A-Extraction time & 1 & 4.96 & 4.96 & 0.2912 & 0.6062 & $14,357.50$ & $14,357.50$ & 0.9317 & 0.3627 \\
\hline B-Temperature & 1 & 2.10 & 2.10 & 0.1233 & 0.7358 & $1.276 \times 10^{5}$ & $1.276 \times 10^{5}$ & 8.28 & 0.0206 \\
\hline C-Ethanol & 1 & 414.72 & 414.72 & 24.34 & 0.0017 & $7.772 \times 10^{5}$ & $7.772 \times 10^{5}$ & 50.43 & 0.0001 \\
\hline \multicolumn{10}{|l|}{ Interaction } \\
\hline $\mathrm{AB}$ & 1 & 10.24 & 10.24 & 0.6010 & 0.4636 & *et & *et & *et & ${ }^{*}$ et \\
\hline $\mathrm{AC}$ & 1 & 12.60 & 12.60 & 0.7397 & 0.4182 & 4529.96 & 4529.96 & 0.2939 & 0.6025 \\
\hline $\mathrm{BC}$ & 1 & 9.92 & 9.92 & 0.5824 & 0.4703 & $54,289.00$ & $54,289.00$ & 3.52 & 0.0974 \\
\hline \multicolumn{10}{|l|}{ Square } \\
\hline $\mathrm{A}^{2}$ & 1 & 9.41 & 9.41 & 0.5524 & 0.4815 & $1.370 \times 10^{5}$ & $1.370 \times 10^{5}$ & 8.89 & 0.0176 \\
\hline $\mathrm{B}^{2}$ & 1 & 0.0885 & 0.0885 & 0.0052 & 0.9446 & 10623.70 & $10,623.70$ & 0.6894 & 0.4305 \\
\hline$C^{2}$ & 1 & 102.34 & 102.34 & 6.01 & 0.0441 & $1.260 \times 10^{5}$ & $1.260 \times 10^{5}$ & 8.17 & 0.0212 \\
\hline Residual & 7 & 119.26 & 17.04 & & & $1.233 \times 10^{5}$ & $15,410.79$ & & \\
\hline Lack of Fit & 3 & 54.77 & 18.26 & 1.13 & 0.4364 & $91,008.99$ & $22,752.25$ & 2.82 & 0.1697 \\
\hline Pure Error & 4 & 64.49 & 16.12 & & & $32,277.34$ & 8069.34 & & \\
\hline $\mathrm{R}^{2}$ & & & & & 0.8253 & & & & 0.9108 \\
\hline $\begin{array}{l}\text { Adequate } \\
\text { precision }\end{array}$ & & & & & 6.4440 & & & & 10.4044 \\
\hline
\end{tabular}

Table 1. The values of factors and responses for extraction optimization of M. pudica in BBD.

Table 2. ANOVA results of BBD. 
Table 2. Cont.

\begin{tabular}{|c|c|c|c|c|c|c|c|c|c|}
\hline \multirow[b]{2}{*}{ Sources } & \multirow[b]{2}{*}{ df } & \multicolumn{4}{|c|}{ TPC } & \multicolumn{4}{|c|}{ TFC } \\
\hline & & $\begin{array}{l}\text { Sum of } \\
\text { Squares }\end{array}$ & $\begin{array}{l}\text { Mean } \\
\text { Square }\end{array}$ & $F$-Value & $p$-Value & $\begin{array}{l}\text { Sum of } \\
\text { Squares }\end{array}$ & $\begin{array}{l}\text { Mean } \\
\text { Square }\end{array}$ & F-Value & $p$-Value \\
\hline Model & 9 & 7469.68 & 829.96 & 6.24 & 0.0123 & $2.369 \times 10^{5}$ & 29608.63 & 4.13 & 0.0304 \\
\hline A-Extraction time & 1 & 705.02 & 705.02 & 5.30 & 0.0548 & 679.88 & 679.88 & 0.0949 & 0.7659 \\
\hline B-Temperature & 1 & 3.59 & 3.59 & 0.0270 & 0.8741 & 7.05 & 7.05 & 0.0010 & 0.9757 \\
\hline C-Ethanol & 1 & 6471.01 & 6471.01 & 48.6 & 0.0002 & $1.781 \times 10^{5}$ & $1.781 \times 10^{5}$ & 24.87 & 0.0011 \\
\hline \multicolumn{10}{|l|}{ Interaction } \\
\hline $\mathrm{AB}$ & 1 & 179.69 & 179.69 & 1.35 & 0.2831 & 17145.28 & 17145.28 & 2.39 & 0.1604 \\
\hline $\mathrm{AC}$ & 1 & 0.2116 & 0.2116 & 0.0016 & 0.9693 & 339.85 & 339.85 & 0.0475 & 0.8330 \\
\hline $\mathrm{BC}$ & 1 & 42.84 & 42.84 & 0.3222 & 0.5880 & 9937.10 & 9937.10 & 1.39 & 0.2727 \\
\hline \multicolumn{10}{|l|}{ Square } \\
\hline $\mathrm{A}^{2}$ & 1 & 1.77 & 1.77 & 0.0133 & 0.9113 & $15,736.65$ & 15736.65 & 2.20 & 0.1765 \\
\hline $\mathrm{B}^{2}$ & 1 & 26.18 & 26.18 & 0.1969 & 0.6706 & *et & ${ }^{*}$ et & *et & *et \\
\hline$C^{2}$ & 1 & 42.42 & 42.42 & 0.3191 & 0.5898 & $16,597.46$ & 16597.46 & 2.32 & 0.1664 \\
\hline Residual & 7 & 930.61 & 132.94 & & & $57,291.98$ & 7161.50 & & \\
\hline Lack of Fit & 3 & 420.62 & 140.21 & 1.10 & 0.4463 & $28,381.17$ & 7095.29 & 0.9817 & 0.5069 \\
\hline Pure Error & 4 & 509.99 & 127.50 & & & $28,910.80$ & 7227.70 & & \\
\hline$R^{2}$ & & & & & 0.8892 & & & & 0.8052 \\
\hline $\begin{array}{l}\text { Adequate } \\
\text { precision }\end{array}$ & & & & & 8.5551 & & & & 6.6924 \\
\hline
\end{tabular}

*et: excluded terms from the model quadratic equation.

\subsubsection{Extract Yield}

The extract yield of M. pudica ranged from 3.1\% to $25.9 \%$. The highest yield (25.9\%) was observed in experimental run 2 under extraction conditions of 30 min extraction time, $60{ }^{\circ} \mathrm{C}$ temperature, and ethanol concentration of $50 \%$. This extraction protocol resulted in a higher yield as compared to a previous study on $M$. pudica extraction, where only $20 \%$ extract yield was obtained using $80 \%$ ethanol as solvent, at room temperature, and an extraction time of 3 days [35]. Based on the ANOVA results in Table 2, only the linear (A) and the quadratic $\left(\mathrm{A}^{2}\right)$ response of the ethanol concentration were highly significant $(p<0.05)$ while the extraction time, temperature, and the variable interactions were less significant $(p>0.05)$.

As the solvent concentration of ethanol decreased from $100 \%$ to $50 \%$, the extract yield increased, as portrayed in Figure 1B. The stronger polar strength of diluted ethanol (water as a diluent) as compared to absolute ethanol might explain the reason behind the higher yield of the crude extract [36]. The outcome of this study revealed a similar pattern with a previous study by Nawaz et al. [37] on the extraction of Phaseolus vulgaris, where the stronger polarity of the solvent resulted in a higher extract yield. The interaction between the solvent and temperature showed a notable effect to increase the extract yield (Figure 1C) since the highest reading was achieved when both the ethanol concentration and temperature were at the lowest levels. On the contrary, earlier reports showed that an increase in temperature could steer up the analyte solubility by the mass transfer rate since it leads to a decrease in surface tension and viscosity, which aids the solvent to reach sample matrices, hence improving the extraction rate [38]. This inconsistency might be due to the intervention of the solvent reaction, which obviously play a significant role in determining plant extraction efficacy apart from the temperature alone. 
A.

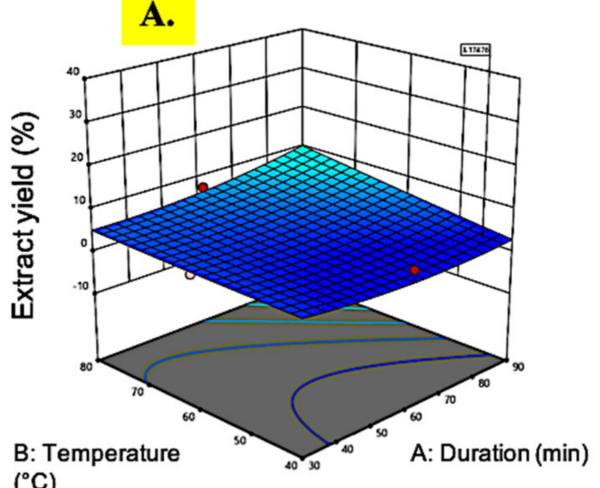

B.

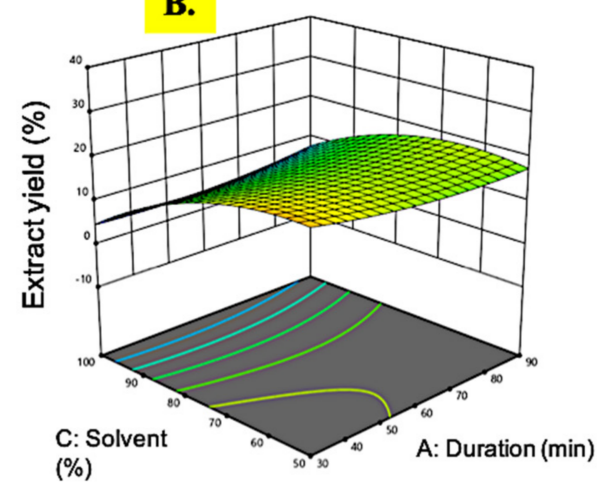

C.

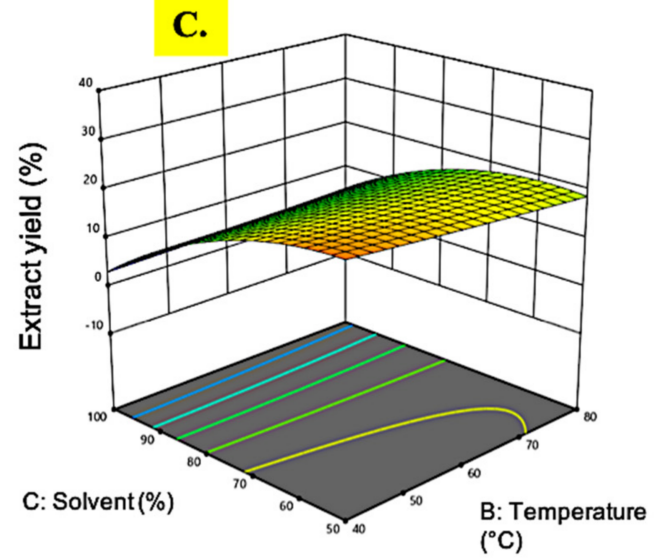

Figure 1. Response surface analysis (3D) of M. pudica extract on crude extract yield (A) effect of temperature and extraction time; (B) effect of extraction time and ethanol concentration; (C) effect of temperature and ethanol concentration.

\subsection{2. $\mathrm{IC}_{50}$ Value}

The $\mathrm{IC}_{50}$ value (half maximal inhibitory concentration) is the concentration of the sample that can scavenge $50 \%$ of DPPH free radical in a DPPH free radical scavenging assay. The $\mathrm{IC}_{50}$ value is inversely proportional to the free radical scavenging activity or the antioxidant property of the sample [39]. A lower $\mathrm{IC}_{50}$ value indicates a higher antioxidant property. The $\mathrm{IC}_{50}$ value from $M$. pudica extracts ranged from $42.0 \mu \mathrm{g} / \mathrm{mL}$ to $975.03 \mu \mathrm{g} / \mathrm{mL}$. The lowest $\mathrm{IC}_{50}$ value was observed in experimental run 3 under the extraction conditions of $60 \mathrm{~min}$ at $40{ }^{\circ} \mathrm{C}$ in $100 \%$ ethanol. The ANOVA of the regression coefficient revealed that the two linear parameters, temperature (B) and ethanol concentration $(C)$, were significant $(p<0.05)$ along with the quadratic effects of extraction time $\left(\mathrm{A}^{2}\right)$ and ethanol concentration $\left(\mathrm{C}^{2}\right)$, which had the greatest impact on the $\mathrm{IC}_{50}$ values (Table 2 ).

Based on Figure 2A, when the $100 \%$ ethanol concentration was used, the $\mathrm{IC}_{50}$ value fluctuated and maintained below $200 \mu \mathrm{g} / \mathrm{mL}$ as the extraction time increased. However, the temperature change did not give any effects on the $\mathrm{IC}_{50}$ value (Figure $2 \mathrm{~B}$ ). Notably, at the $50 \%$ ethanol concentration, an increase in temperature gave a negative effect on the $\mathrm{IC}_{50}$ value, where the reading increased to nearly $700 \mu \mathrm{g} / \mathrm{mL}$. Contrary to a previous report on Barleria lupulina extracts [40], free radical scavenging activity was reduced with increasing ethanol concentration, while it was significantly increased with a prolonged extraction time. Although a longer extraction time might increase the quantity of extracted analytes [41], there is a possibility that the extracted compounds are degraded during the process. Therefore, there is a need to strike a balance among the extraction conditions to find the optimal values necessary to achieve the maximal $\mathrm{IC}_{50}$ value. 
A.

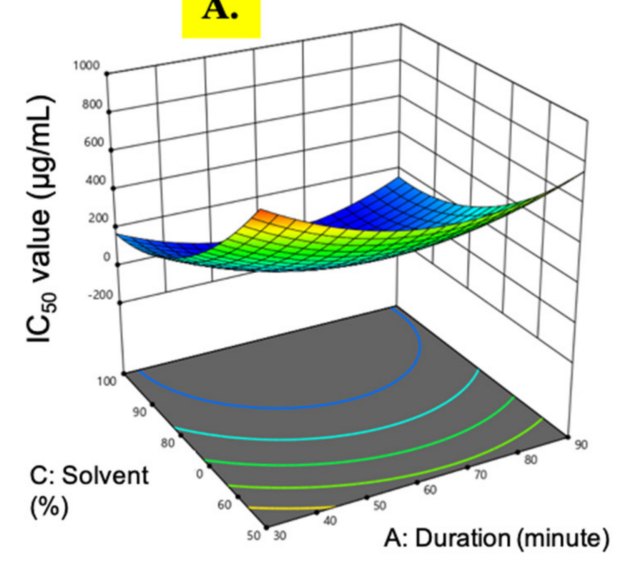

B.

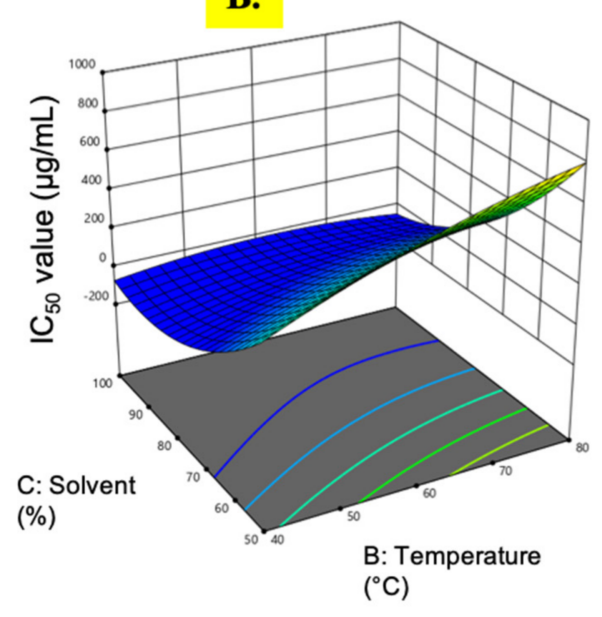

Figure 2. Response surface analysis (3D) of $M$. pudica extract on the $\mathrm{IC}_{50}$ value (A) effect of extraction time and ethanol concentration; $(\mathbf{B})$ effect of temperature and ethanol concentration.

\subsubsection{Total Phenolic Content}

TPC was measured using gallic acid equivalent quantification. The TPC in the $M$. pudica extract ranged from 14.51 to $91.98 \mathrm{mg} \mathrm{GAE} / \mathrm{g}$. The highest TPC (91.98 mg GAE/g) was observed in experimental run 10 with the extract conditions of $90 \mathrm{~min}$ at $60{ }^{\circ} \mathrm{C}$ in a $100 \%$ ethanol concentration. The results observed in this investigation were far higher than those observed by [42], where the highest TPC in M. pudica extract was only $60.07 \mathrm{mg}$ GAE/g obtained through unoptimized solvent extraction. However, a study conducted by Ganesan et al. [26] using microwave-assisted extraction on M. pudica obtained a much higher recovery of TPC up to $640.0 \mathrm{mg} \mathrm{GAE} / \mathrm{g}$. This discrepancy could be attributed to the rapid heating of microwave irradiation, which promotes cellular matrix breakdown and increases phenolic compound release [43]. Based on Table 2, the regression coefficient showed that only the ethanol concentration (C) was highly significant on the TPC $(p<0.05)$ while all the other quadratic and interaction terms showed no notable effects $(p>0.05)$.

The 3D plot graphs in Figure 3 demonstrates that the ethanol concentration was a single significant factor influencing the TPC value. In Figure 3A, it can be seen that the TPC value decreased marginally even at the lowest extraction time and temperature level. A previous study on wheat species extraction conformed the current finding that the extraction time did not have a significant role in TPC accumulation in plant extracts [44]. On the contrary, Guido and Moreira [45] reported that extraction temperature was important for phenols extraction purposes. At higher temperatures, the compounds' solubility increases while the surface tension decreases, resulting in weaker phenolicprotein and phenolic-polysaccharide linkages, hence easing the movement of phenolic compounds into the extraction solvent [46]. However, it was found that high extraction temperatures negatively affect the phenol extraction of brewer's spent grain, as described by Ogbole et al. [47] and Mousinho et al. [48]. Therefore, the effects of temperature on phenolic compound extraction are still not fully understood and are rather plant species dependent. 
A.

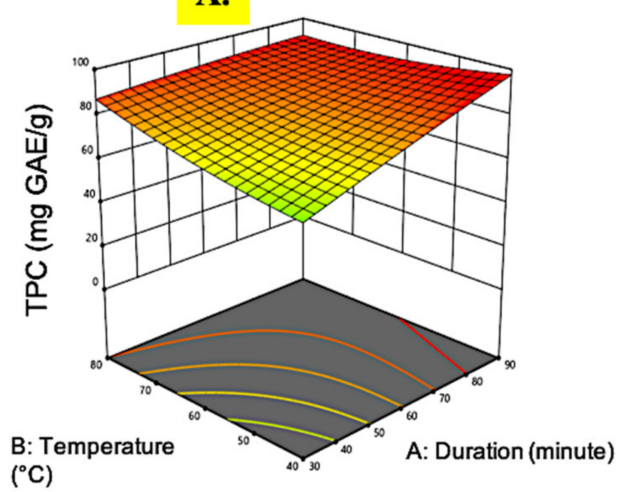

$\left({ }^{\circ} \mathrm{C}\right)$
B.

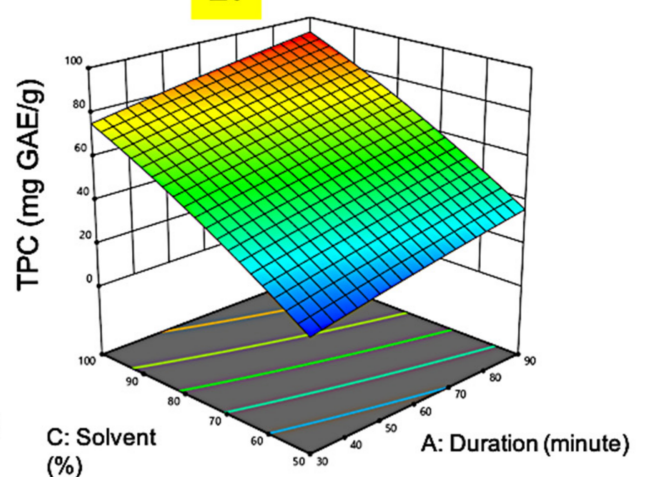

(\%)

C.

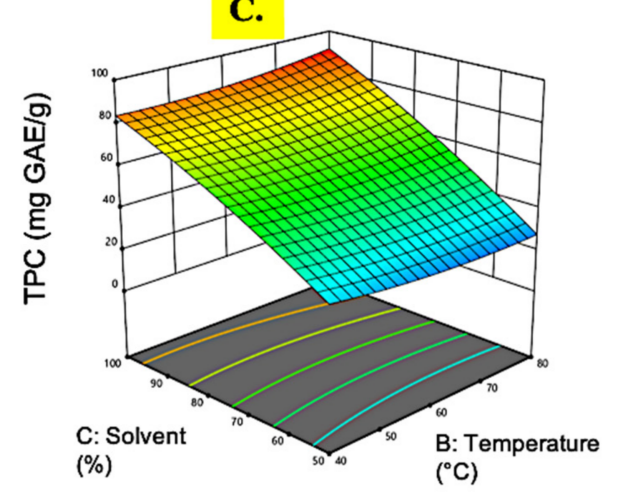

Figure 3. Response surface analysis (3D) of M. pudica extract on TPC (A) effect of extraction time and temperature; (B) effect of extraction time and ethanol concentration; (C) effect of temperature and ethanol concentration.

\subsubsection{Total Flavonoid Content}

Flavonoids are a family of natural phenolic chemicals produced as bioactive secondary metabolites in plants and are responsible for taste, color, and pharmacological properties. They are powerful antioxidants with therapeutic values, such as anti-inflammatory and anticancer [49]. The TFC in M. pudica extracts in this study was measured using quercetin equivalent quantification. The TFC values recovered from $M$. pudica extracts ranged from 204.44 to $606.31 \mathrm{mg}$ QE/g. The ANOVA results in Table 2 and the 3D plot in Figure 4 showed a similar pattern as in the TPC recovery. The extraction conditions employed in this study resulted in an exceptional amount of flavonoids accumulation, 144-fold higher as compared to an extraction of M. pudica using ultrasonic cleaner [50], which was about $4.2 \mathrm{mg} \mathrm{QE} / \mathrm{g}$ only. This might be due to the differences in the extraction techniques employed, where the former incorporated a chemical ethanol extraction with optimal multi-variable interactions, while the latter used a physical ultrasonic approach. Similar to Ganesan et al. [26], the recovery of TFC from microwave-assisted extraction of M. pudica resulted in only $61.76 \mathrm{mg} \mathrm{RU} / \mathrm{g}$. A high temperature and radiation energy by microwave treatment might disrupt certain bioactive compounds, hence the low recovery of compounds of interest [51]. 

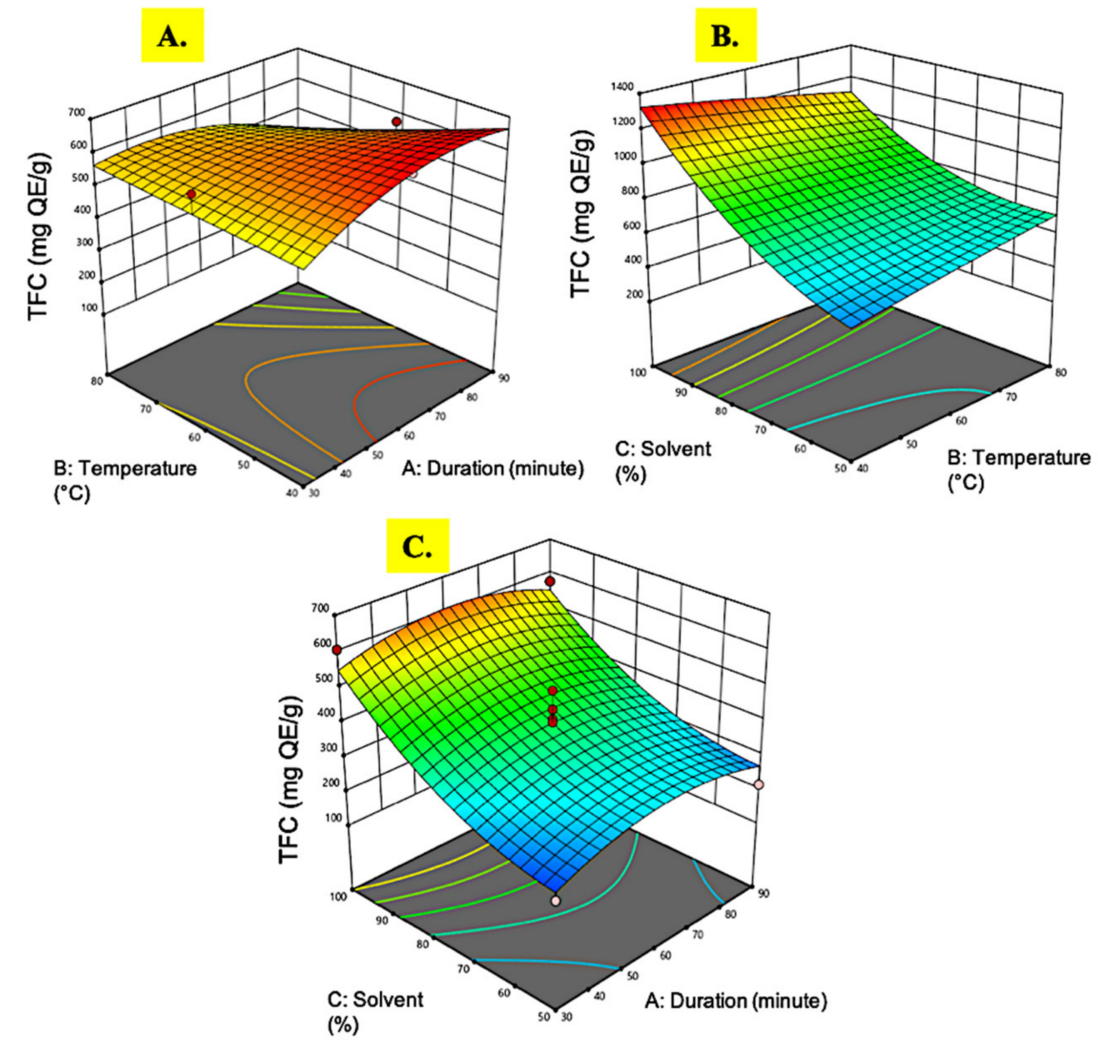

Figure 4. Response surface analysis (3-D) of M. pudica extract on TFC (A) effect of extraction time and temperature; (B) effect of temperature and ethanol concentration; (C) effect of extraction time and ethanol concentration.

\subsection{Correlation Analysis}

Based on Table 3, the correlation values of $\mathrm{IC}_{50}$ value to TPC and TFC were -0.743 and -0.600 , respectively. It can be deduced that the phenolic compounds, which are the predominant components in the M. pudica extracts, contributed to the low $\mathrm{IC}_{50}$ value. A low $\mathrm{IC}_{50}$ value indicates a high accumulation of antioxidative compounds as a low concentration of the extract is sufficient to scavenge at least half of the DPPH free radical. Patro et al. [32] revealed that ethyl acetate extract of $M$. pudica showed a high level of total phenolic and flavonoid contents, and exhibited a significant linear relationship with its antioxidant activity, which was conformed with the present study. The solvent concentration of ethanol had similar impacts to TPC and TFC. Both TPC and TFC recovery in the extracts decreased with increasing polarity of the solvent used. These results reflect those of Sedraoui et al. [52], who also reported that ethanol concentration, solvent-to-sample ratio, and temperature were among the significant $(p<0.05)$ factors affecting the antioxidants extraction from Phoenix dactylifera, a date palm species.

Table 3. Correlation analysis between extraction conditions and responses.

\begin{tabular}{cccccccc}
\hline & $\begin{array}{c}\text { A: Extraction } \\
\text { Time }\end{array}$ & $\begin{array}{c}\text { B: } \\
\text { Temperature }\end{array}$ & $\begin{array}{c}\text { C: Ethanol } \\
\text { Concentration }\end{array}$ & $\begin{array}{c}\text { Crude } \\
\text { Extract Yield }\end{array}$ & IC $_{50}$ Value & TPC & TFC \\
\hline A: Extraction time & & & & & & & \\
B: Temperature & & & & & & \\
C: Ethanol & & & & & 0.612 & -0.658 & -0.749 \\
concentration & -0.085 & 0.055 & -0.779 & -0.612 & -0.743 & -0.600 \\
Extract Yield & -0.102 & 0.304 & -0.750 & -0.658 & -0.743 & 0.832 \\
IC 50 value & 0.290 & 0.021 & 0.878 & -0.749 & -0.600 & 0.832 \\
TPC & 0.048 & -0.005 & 0.778 & & & \\
TFC & & & & & & \\
\hline
\end{tabular}




\subsection{Verification of Quadratic Model}

Design-Expert software was used in this study to search for a set of factor levels that satisfied all of the requirements placed on each of the factors and responses. The optimization goals (i.e., none, maximum, minimum, target, or in range) were set for all factors and responses in which the desirability value was obtained. To acquire a good set of conditions with high desirability value, the three variables: (i) extraction time, (ii) temperature, and (iii) ethanol concentration, were set within range while the responses; $\mathrm{IC}_{50}$ values, were set at the minimum; and TPC and TFC were set at the maximum. Since extract yield was negatively correlated with the accumulation of the antioxidative compound, it was omitted in the verification part, in order to achieve the main objective of this study. The "importance" of goals for all variables and responses were considered to be equally important and set at 5 . The desirability ramps that were developed from optimum points via numerical optimization are exhibited in Figure 5.
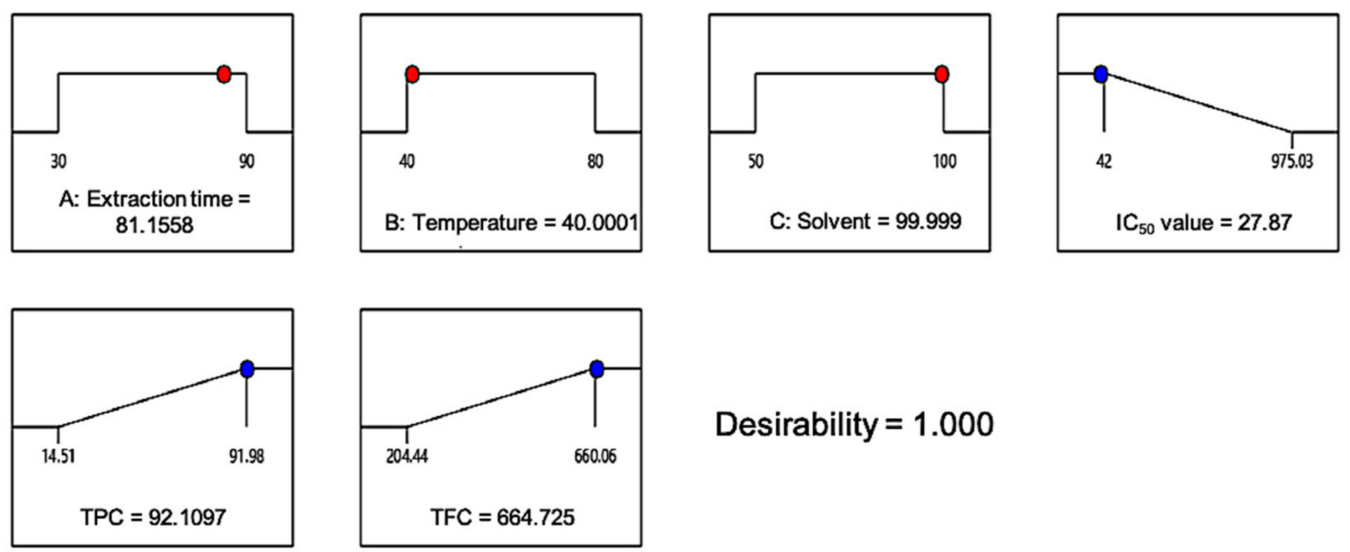

Desirability $=1.000$

Figure 5. Desirability ramp for numerical optimization of the $\mathrm{IC}_{50}$ value and total phenolic and total flavonoid content.

To validate the generated quadratic models, a triplicate experiment was employed using the predetermined factor levels. Based on Figure 5, the predicted optimum level of factors (1.000 desirability value) with the condition of $82 \mathrm{~min}$ extraction time, $40{ }^{\circ} \mathrm{C}$ temperature, and $100 \%$ ethanol concentration would yield $27.87 \mu \mathrm{g} / \mathrm{mL}$ of IC50 value, $92.11 \mathrm{mg}$ GAE$/ \mathrm{g}$ of TPC, and $664.73 \mathrm{mg}$ QE $/ \mathrm{g}$ of TFC. In the actual experiment, the $\mathrm{IC}_{50}$ value obtained was $51.02 \mu \mathrm{g} / \mathrm{mL}$, while the TPC and TFC obtained were $68.5 \mathrm{mg}$ GAE $/ \mathrm{g}$ and $659.85 \mathrm{mg} \mathrm{QE} / \mathrm{g}$, respectively. The high similarity percentage between the actual and predicted responses indicated that the regression model was suitable and relevant as a reference (Table 4).

Table 4. Predicted and actual values of responses.

\begin{tabular}{cccc}
\hline & IC $_{\mathbf{5 0}}$ Value, $\boldsymbol{\mu g} / \mathbf{m L}$ & TPC, $\mathbf{m g ~ G A E} / \mathbf{g}$ & TFC, $\mathbf{~ m g ~ Q E / g ~}$ \\
\hline Predicted & 27.87 & 92.11 & 664.73 \\
Actual & $51.02 \pm 2.07$ & $68.5 \pm 3.15$ & $659.85 \pm 31.46$ \\
Similarity percentage, $\%$ & 54.63 & 74.36 & 99.27 \\
\hline
\end{tabular}

\subsection{Effect of the Optimized M. pudica Extracts on 3T3-L1 Cell Viability}

MTT assay is a sensitive colourimetric method that assesses the cytotoxic effect of the extracts on cell viability. It measures the reduction of yellow-colored MTT by mitochondrial succinate dehydrogenase into an insoluble dark purple formazan product. The optimized M. pudica extracts recovered from the previous experiment were tested on 3T3-L1 preadipocytes to assess their cytotoxicity level at different concentrations (50, 100, 200, 400, and $800 \mu \mathrm{g} / \mathrm{mL}$ ). The cell viability results in Figure 6 recorded a non-significant 
difference between the treated cells and the control $(p>0.05)$. These findings suggest that the optimized M. pudica ethanolic extracts caused no harm to 3T3-L1 cells even at relatively high concentrations. On the contrary, M. pudica ethanolic extract was found to be cytotoxic to Dalton's ascites lymphoma cells at an $\mathrm{IC}_{50}$ value of $90.33 \mu \mathrm{g} / \mathrm{mL}$ [53] while the methanolic extract of $M$. pudica was cytotoxic to the Rhabdomyosarcoma cell line with a $\mathrm{CC}_{50}$ value of $2.03 \mu \mathrm{g} / \mathrm{mL}$ [47]. Since the optimized M. pudica extracts were biocompatible to the 3T3-L1 cells, they were subsequently evaluated for glucose uptake assay using 50 and $100 \mu \mathrm{g} / \mathrm{mL}$ extract concentrations.

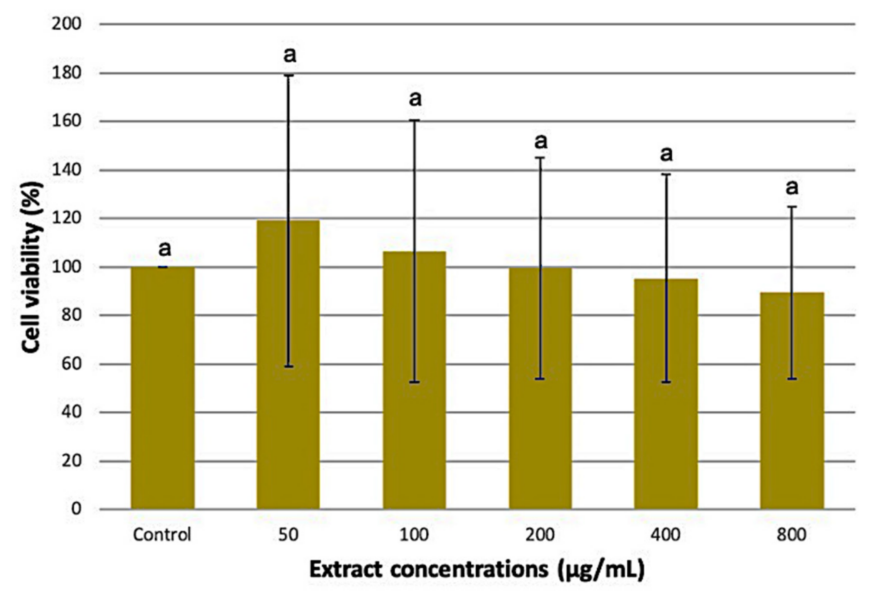

Figure 6. Effects of increasing concentrations of M. pudica extract on 3T3-L1 cell lines. Values are expressed as mean \pm SE $(n=3)$. Different letters indicate statistically significant differences between factors (one-way ANOVA + Tukey post-hoc test at $p<0.05$ ).

3.5. Effects of the Optimized M. Pudica Extracts on Stimulating Glucose Uptake in 3T3-L1 Adipocyte Cells

A preliminary antidiabetic capacity of M. pudica extracts was assessed on matured adipocytes of the 3T3-L1 cell line using 2-NBDG as a marker for glucose metabolism. The increase in relative fluorescence intensity (rfi) exhibited the elevation of 2-NBDG absorption into cells, indicating that the extracts may have insulin-mimetic characteristics [48]. Based on Figure 7, cells treated with only insulin $(0.58 \mathrm{mg} / \mathrm{mL})$ were prepared as the reference treatment and recorded at $314.0 \mathrm{rfi}$. For treatment of extracts alone without insulin, the rfi recorded were 748.67 and 1444.33 for $50 \mu \mathrm{g} / \mathrm{mL}$ and $100 \mu \mathrm{g} / \mathrm{mL}$ of extracts, respectively. The rfi was significantly increased for the treatment of extracts in the presence of insulin, with $1646.0 \mathrm{rfi}$ for $50 \mu \mathrm{g} / \mathrm{mL}$ and $1297.67 \mathrm{rfi}$ for $100 \mu \mathrm{g} / \mathrm{mL}$ of extracts. Surprisingly, the concoction between M. pudica extracts and insulin exhibited a synergistic effect, where the glucose uptake rate of the extracts with insulin doubled as compared to extracts alone, and six-fold as compared to insulin alone. There was a significant difference between the glucose uptake rate in the treatment of extracts with insulin and without insulin $(p<0.05)$. Although a higher concentration of extracts $(100 \mu \mathrm{g} / \mathrm{mL})$ combined with insulin exhibited a marginally lower rate of glucose uptake as compared to $50 \mu \mathrm{g} / \mathrm{mL}$, but there was no significant difference in relation to the concentrations of extract $(p>0.05)$.

Insulin is a hormone that controls blood glucose levels by triggering a variety of physiological reactions in the tissues it targets. It facilitates glucose absorption from the blood by promoting membrane trafficking of the glucose transporter GLUT4 from GLUT4 storage vesicles to the plasma membrane in adipose tissue and skeletal muscle [54]. Insulin stimulation of adipose tissue for glucose absorption is essential for decreasing postprandial blood glucose levels. One of the key causes in the development of type 2 diabetes is abnormal control of this mechanism. A study revealed that $M$. pudica seeds had an antidiabetic impact via increasing pancreatic insulin and $\alpha$-amylase production, as well as flavonoids and phenols, where it significantly decreased lipid peroxidation and enhanced endogenous antioxidant levels [55]. Another study discovered that methanolic 
extract of M. pudica demonstrated substantial antidiabetic and antihyperlipidemic effects on streptozotocin-induced diabetes mellitus in rats [56]. The antidiabetic potential of the methanolic M. pudica extract is equivalent to that of glibenclamide, as indicated by the normalization of blood glucose level tests. Furthermore, Rajendiran et al. [57] and Yupparach and Konsue [58] revealed that ethanolic extract of $M$. pudica leaves exhibited its maximal antidiabetic potential at a dose of $300 \mathrm{mg} / \mathrm{kg} / \mathrm{bwt}$ against a high-fat diet and streptozotocin-induced type 2 diabetes mellitus rats.

Glucose uptake stimulation assays on 3T3-L1 cells have been performed extensively on various plant species but none of them used M. pudica. A study conducted on the extracts of Sclerocarya birrea and Ziziphus mucronata at a concentration range from 1.56 to $6.25 \mu \mathrm{g} / \mathrm{mL}$ significantly enhanced the glucose uptake in 3T3-L1 cells, which was much greater than that demonstrated by insulin at $6.25 \mu \mathrm{g} / \mathrm{mL}$ [48]. Likewise, the extracts of Coix lachryma-jobi exhibited a similar glucose uptake stimulation on 3T3-L1 cells at $30 \mu \mathrm{g} / \mathrm{mL}$, which was four-fold higher than the basal level and just slightly lower than the insulin at $200 \mathrm{nM}$ [59]. The findings of the present study inferred that M. pudica may have hypoglycemic effects and antidiabetic properties that mimic insulin activity. This is the first report to demonstrate an increased glucose uptake in adipocyte cells induced by the ethanolic extracts of M. pudica.

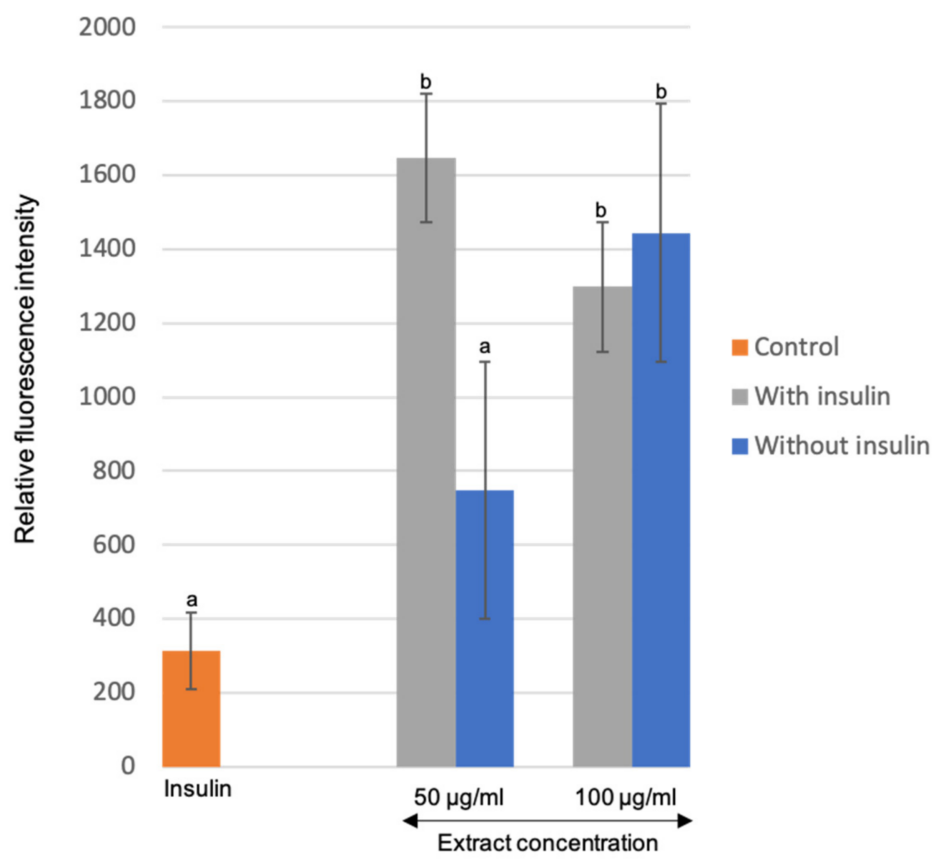

Figure 7. Effects of the M. pudica extracts on glucose uptake by 3T3-L1 matured adipocyte cells. Values are expressed as mean $\pm \mathrm{SE}(n=3)$. Different letters indicate statistically significant differences between factors (one-way ANOVA + Tukey post-hoc test at $p<0.05$ ).

\section{Conclusions}

Herbal medicine has long been used in many cultures across the world as a costeffective therapeutic alternative. In this study, an RSM-based optimization was successfully employed to obtain the optimum extraction conditions of $M$. pudica while maximizing the accumulation of antioxidant compounds. The optimized extraction conditions achieved in this study were $82 \mathrm{~min}$ (extraction time), $40{ }^{\circ} \mathrm{C}$ (temperature), and $100 \%$ ethanol (solvent concentration). The lowest $\mathrm{IC}_{50}$ value recorded was $42.0 \mu \mathrm{g} / \mathrm{mL}$ using $100 \%$ ethanol as compared to $975.03 \mu \mathrm{g} / \mathrm{mL}$ using $50 \%$ ethanol. The highest TPC and TFC value recorded was $94.015 \mathrm{mg} \mathrm{GAE} / \mathrm{g}$ and $1320.13 \mathrm{mg}$ QE/g using $100 \%$ ethanol, which was five-fold and three-fold higher as compared to using $50 \%$ and $75 \%$ ethanol, respectively. It was found that crude extract yield was inversely proportional to TPC and TFC. The results indicated 
that ethanol concentration was the most significant factor, having the greatest impact on the accumulation of antioxidant compounds in the extract. The cell viability results recorded a viability level of above $50 \%$ for all treatments. The glucose uptake in 3T3-L1 cells treated with $50 \mu \mathrm{g} / \mathrm{mL}$ extract combined with insulin was five-fold higher than the control.

The results of the present work suggest that there is a possible correlation between antioxidants' accumulation in M. pudica extracts and its antidiabetic effects. The high level of free radical scavenging activity, together with the ability to stimulate glucose uptake in adipocyte cells, indicated that $M$. pudica could be a potential biocompatible candidate of a herbal supplement containing active ingredients, which could fight against free-radicalassociated oxidative damage, and hence reduce the detrimental effects of diabetes. To confirm and elucidate the mechanism behind this action, further research on the bioactive profile of the optimized ethanolic M. pudica extracts should be conducted in the future.

Author Contributions: Conceptualization, N.S.B.; methodology, N.S.B.; software, N.S.B.; validation, N.S.B. and M.A.M.R.; formal analysis, N.S.B. and M.A.M.B.; investigation, N.S.B. and M.A.M.B.; resources, N.S.B.; data curation, N.S.B. and M.A.M.B.; writing-original draft preparation, N.S.B.; writing-review and editing, N.S.B., M.A.M.R., Z.M.S., A.M.A., Z.A.R., M.E.K. and N.A.A.R.; visualization, N.S.B.; supervision, Z.M.S., A.M.A., Z.A.R. and M.E.K.; project administration, Z.M.S., A.M.A., Z.A.R., M.E.K., and N.A.A.R.; funding acquisition, Z.M.S. and A.M.A. All authors have read and agreed to the published version of the manuscript.

Funding: This work was supported by Putra Grant GP/2018/9602200 financed by Universiti Putra Malaysia. The APC was funded by the Research Management Centre, Universiti Putra Malaysia.

Institutional Review Board Statement: Not applicable.

Informed Consent Statement: Not applicable.

Data Availability Statement: Not applicable.

Acknowledgments: The authors gratefully acknowledge the financial assistance granted by Graduate Research Fellowship (GRF), Universiti Putra Malaysia.

Conflicts of Interest: The authors declare no conflict of interest.

\section{References}

1. Tunna, T.S.; Ahmed, Q.U.; Uddin, A.B.M.H.; Sarker, M.Z.I. Weeds as Alternative Useful Medicinal Source: Mimosa Pudica Linn. on Diabetes Mellitus and Its Complications. Adv. Mater. Res. 2014, 995, 49-59. [CrossRef]

2. Yuan, K.; Lu, J.L.; Jia, A.; Zhu, J.X. Two New C-Glycosylflavones from Mimosa Pudica. Chin. Chem. Lett. 2007, 18, 1231-1234. [CrossRef]

3. Chandran, R.P.; Deepak, V.; Krishna, S.; Fathima, S.; Thaha, A.; Raj, J. Analysis of Phytochemical Constituents and Anthelmintic Activity of Leaf Extracts of Mimosa pudica L. Asian J. Biomed. Pharm. Sci. 2018, 8, 1-5. [CrossRef]

4. Sriram, S.; Vaidyanathan, M.; Venkatesh, K.; Nayagam, A.A.J. GC-MS Study and Phytochemical Profiling of Mimosa Pudica Linn. J. Pharm. Res. 2011, 4, 741-742.

5. Champanerkar, P.A.; Vaidya, V.V.; Shailajan, S.; Menon, S.N. A Sensitive, Rapid and Validated Liquid Chromatography-Tandem Mass Spectrometry (LC-MS-MS) Method for Determination of Mimosine in Mimosa Pudica Linn. Nat. Sci. 2010, 2, 713-717. [CrossRef]

6. Ahuchaogu, A.A.; Chukwu, O.J.; Echeme, J.O. Secondary Metabolites from Mimosa Pudica: Isolation, Purification and NMR Characterization. IOSR J. Appl. Chem. 2017, 10, 15-20. [CrossRef]

7. Kumar, V. Phytochemical, Pharmacological Activities and Ayurvedic Significances of Magical Plant Mimosa Pudica Linn. Mini-Rev. Org. Chem. 2021, 18, 296-312. [CrossRef]

8. Alatrach, M.; Agyin, C.; Mehta, R.; Adams, J.; DeFronzo, R.A.; Abdul-Ghani, M. Glucose-Mediated Glucose Disposal at Baseline Insulin Is Impaired in IFG. J. Clin. Endocrinol. Metab. 2019, 104, 163-171. [CrossRef]

9. Chaudhury, A.; Duvoor, C.; Reddy Dendi, V.S.; Kraleti, S.; Chada, A.; Ravilla, R.; Marco, A.; Shekhawat, N.S.; Montales, M.T.; Kuriakose, K.; et al. Clinical Review of Antidiabetic Drugs: Implications for Type 2 Diabetes Mellitus Management. Front. Endocrinol. 2017, 8, 6. [CrossRef]

10. Liu, J.-X.; Shen, S.-N.; Tong, Q.; Wang, Y.-T.; Lin, L.-G. Honokiol Protects Hepatocytes from Oxidative Injury through Mitochondrial Deacetylase SIRT3. Eur. J. Pharmacol. 2018, 834, 176-187. [CrossRef]

11. Afrisham, R.; Aberomand, M.; Ghaffari, M.A.; Siahpoosh, A.; Jamalan, M. Inhibitory Effect of Heracleum Persicum and Ziziphus Jujuba on Activity of Alpha-Amylase. J. Bot. 2015, 2015, 1-8. [CrossRef]

12. Giacco, F.; Brownlee, M. Oxidative Stress and Diabetic Complications. Circ. Res. 2010, 107, 1058-1070. [CrossRef] 
13. Mohammadi, S.; Montasser Kouhsari, S.; Monavar Feshani, A. Antidiabetic Properties of the Ethanolic Extract of Rhus Coriaria Fruits in Rats. Daru 2010, 18, 270-275.

14. Maritim, A.C.; Sanders, R.A.; Watkins, J.B. Diabetes, Oxidative Stress, and Antioxidants: A Review. J. Biochem. Mol. Toxicol. 2003, 17, 24-38. [CrossRef]

15. Carocho, M.; Ferreira, I.C.F.R. A Review on Antioxidants, Prooxidants and Related Controversy: Natural and Synthetic Compounds, Screening and Analysis Methodologies and Future Perspectives. Food Chem. Toxicol. 2013, 51, 15-25. [CrossRef] [PubMed]

16. Oguntibeju, O.O. Type 2 Diabetes Mellitus, Oxidative Stress and Inflammation: Examining the Links. Int. J. Physiol. Pathophysiol. Pharmacol. 2019, 11, 45-63.

17. Bayani, U.; Ajay, S.V.; Paolo, Z.; Mahajan, R.T. Oxidative Stress and Neurodegenerative Diseases: A Review of Upstream and Downstream Antioxidant Therapeutic Options. Curr. Neuropharmacol. 2009, 7, 65-74.

18. Hariprasath, L.; Jegadeesh, R.; Arjun, P.; Raaman, N. In Vitro Propagation of Senecio Candicans DC and Comparative Antioxidant Properties of Aqueous Extracts of the in Vivo Plant and in Vitro-Derived Callus. S. Afr. J. Bot. 2015, 98, 134-141. [CrossRef]

19. Engwa, G.A. Free Radicals and the Role of Plant Phytochemicals as Antioxidants against Oxidative Stress-Related Diseases. In Phytochemicals-Source of Antioxidants and Role in Disease Prevention; InTech: London, UK, 2018.

20. Muriel, P.; Rivera-Espinoza, Y. Beneficial Drugs for Liver Diseases. J. Appl. Toxicol. 2008, 28, 93-103. [CrossRef] [PubMed]

21. Lin, J.Y.; Tang, C.Y. Determination of Total Phenolic and Flavonoid Contents in Selected Fruits and Vegetables, as Well as Their Stimulatory Effects on Mouse Splenocyte Proliferation. Food Chem. 2007, 101, 140-147. [CrossRef]

22. Song, H.; Zhang, Q.; Zhang, Z.; Wang, J. In Vitro Antioxidant Activity of Polysaccharides Extracted from Bryopsis Plumosa. Carbohydr. Polym. 2010, 80, 1057-1061. [CrossRef]

23. Guerriero, G.; Berni, R.; Muñoz-Sanchez, J.A.; Apone, F.; Abdel-Salam, E.M.; Qahtan, A.A.; Alatar, A.A.; Cantini, C.; Cai, G.; Hausman, J.F.; et al. Production of Plant Secondary Metabolites: Examples, Tips and Suggestions for Biotechnologists. Genes 2018, 9, 309. [CrossRef]

24. Najib, T.; Solgi, M.; Farazmand, A.; Heydarian, S.M.; Nasernejad, B. Optimization of Sulfate Removal by Sulfate Reducing Bacteria Using Response Surface Methodology and Heavy Metal Removal in a Sulfidogenic UASB Reactor. J. Environ. Chem. Eng. 2017, 5, 3256-3265. [CrossRef]

25. Zolgharnein, J.; Shahmoradi, A.; Ghasemi, J.B. Comparative Study of Box-Behnken, Central Composite, and Doehlert Matrix for Multivariate Optimization of $\mathrm{Pb}$ (II) Adsorption onto Robinia Tree Leaves. J. Chemom. 2013, 27, 12-20. [CrossRef]

26. Ganesan, V.; Gurumani, V.; Kunjiappan, S.; Panneerselvam, T.; Somasundaram, B.; Kannan, S.; Chowdhury, A.; Saravanan, G.; Bhattacharjee, C. Optimization and Analysis of Microwave-Assisted Extraction of Bioactive Compounds from Mimosa Pudica L. Using RSM \& ANFIS Modeling. J. Food Meas. Charact. 2018, 12, 228-242.

27. Sheng, Z.; Zhao, J.; Muhammad, I.; Zhang, Y. Optimization of Total Phenolic Content from Terminalia Chebula Retz. Fruits Using Response Surface Methodology and Evaluation of Their Antioxidant Activities. PLoS ONE 2018, 13, e0202368. [CrossRef]

28. Mokrani, A.; Madani, K. Effect of Solvent, Time and Temperature on the Extraction of Phenolic Compounds and Antioxidant Capacity of Peach (Prunus Persica L.) Fruit. Sep. Purif. Technol. 2016, 162, 68-76. [CrossRef]

29. Dirar, A.I.; Alsaadi, D.H.M.; Wada, M.; Mohamed, M.A.; Watanabe, T.; Devkota, H.P. Effects of Extraction Solvents on Total Phenolic and Flavonoid Contents and Biological Activities of Extracts from Sudanese Medicinal Plants. S. Afr. J. Bot. 2019, 120, 261-267. [CrossRef]

30. Akowuah, G.A.; Ismail, Z.; Norhayati, I.; Sadikun, A. The Effects of Different Extraction Solvents of Varying Polarities on Polyphenols of Orthosiphon Stamineus and Evaluation of the Free Radical-Scavenging Activity. Food Chem. 2005, 93, $311-317$. [CrossRef]

31. Pin, K.Y.; Chuah, A.L.; Rashih, A.A.; Mazura, M.P.; Fadzureena, J.; Vimala, S.; Rasadah, M. Antioxidant and Anti-Inflammatory Activities of Extracts of Betel Leaves (Piper Betle) from Solvents with Different Polarities. J. Trop. For. Sci. 2010, 22, 448-455.

32. Patro, G.; Bhattamisra, S.; Mohanty, B.; Sahoo, H. In Vitro and in Vivo Antioxidant Evaluation and Estimation of Total Phenolic, Flavonoidal Content of Mimosa pudica L. Pharmacogn. Res. 2016, 8, 22-28. [CrossRef]

33. Ibrahim, M.M.; AL Sahli, A.A.A.; Alaraidh, I.A.; Al-Homaidan, A.A.; Mostafa, E.M.; EL-Gaaly, G.A. Assessment of Antioxidant Activities in Roots of Miswak (Salvadora persica) Plants Grown at Two Different Locations in Saudi Arabia. Saudi J. Biol. Sci. 2015, 22, 168-175. [CrossRef] [PubMed]

34. Chandra, S.; Khan, S.; Avula, B.; Lata, H.; Yang, M.H.; ElSohly, M.A.; Khan, I.A. Assessment of Total Phenolic and Flavonoid Content, Antioxidant Properties, and Yield of Aeroponically and Conventionally Grown Leafy Vegetables and Fruit Crops: A Comparative Study. Evid.-Based Complement. Altern. Med. 2014, 2014, 1-9. [CrossRef]

35. Ijaz, S.; Shoaib Khan, H.M.; Anwar, Z.; Talbot, B.; Walsh, J.J. HPLC Profiling of Mimosa Pudica Polyphenols and Their NonInvasive Biophysical Investigations for Anti-Dermatoheliotic and Skin Reinstating Potential. Biomed. Pharmacother. 2019, 109, 865-875. [CrossRef]

36. Zhang, Z.-S.; Li, D.; Wang, L.-J.; Ozkan, N.; Chen, X.D.; Mao, Z.-H.; Yang, H.-Z. Optimization of Ethanol-Water Extraction of Lignans from Flaxseed. Sep. Purif. Technol. 2007, 57, 17-24. [CrossRef]

37. Nawaz, H.; Shad, M.A.; Rehman, N.; Andaleeb, H.; Ullah, N. Effect of Solvent Polarity on Extraction Yield and Antioxidant Properties of Phytochemicals from Bean (Phaseolus vulgaris) Seeds. Braz. J. Pharm. Sci. 2020, 56, 56. [CrossRef] 
38. Barchan, A.; Bakkali, M.; Arakrak, A.; Pagán, R.; Laglaoui, A. The Effects of Solvents Polarity on the Phenolic Contents and Antioxidant Activity of Three Mentha Species Extracts. Int. J. Curr. Microbiol. Appl. Sci. 2014, 3, $399-412$.

39. Aykul, S.; Martinez-Hackert, E. Determination of Half-Maximal Inhibitory Concentration Using Biosensor-Based Protein Interaction Analysis. Anal. Biochem. 2016, 508, 97-103. [CrossRef]

40. Ismail-Suhaimy, N.W.; Gani, S.S.A.; Zaidan, U.H.; Halmi, M.I.E.; Bawon, P. Optimizing Conditions for Microwave-Assisted Extraction of Polyphenolic Content and Antioxidant Activity of Barleria Lupulina Lindl. Plants 2021, 10, 682. [CrossRef] [PubMed]

41. Dahmoune, F.; Nayak, B.; Moussi, K.; Remini, H.; Madani, K. Optimization of Microwave-Assisted Extraction of Polyphenols from Myrtus communis L. Leaves. Food Chem. 2015, 166, 585-595. [CrossRef] [PubMed]

42. Tunna, T.S.; Zaidul, I.S.M.; Ahmed, Q.U.; Ghafoor, K.; Al-Juhaimi, F.Y.; Uddin, M.S.; Hasan, M.; Ferdous, S. Analyses and Profiling of Extract and Fractions of Neglected Weed Mimosa Pudica Linn. Traditionally Used in Southeast Asia to Treat Diabetes. S. Afr. J. Bot. 2015, 99, 144-152. [CrossRef]

43. Weremfo, A.; Adulley, F.; Adarkwah-Yiadom, M. Simultaneous Optimization of Microwave-Assisted Extraction of Phenolic Compounds and Antioxidant Activity of Avocado (Persea Americana Mill.) Seeds Using Response Surface Methodology. J. Anal. Methods Chem. 2020, 2020, 1-11. [CrossRef] [PubMed]

44. Liyana-Pathirana, C.M.; Shahidi, F. Antioxidant and Free Radical Scavenging Activities of Whole Wheat and Milling Fractions. Food Chem. 2007, 101, 1151-1157. [CrossRef]

45. Guido, L.F.; Moreira, M.M. Techniques for Extraction of Brewer's Spent Grain Polyphenols: A Review. Food Bioprocess Technol. 2017, 10, 1192-1209. [CrossRef]

46. Viacava, G.E.; Roura, S.I.; Agüero, M.V. Optimization of Critical Parameters during Antioxidants Extraction from Butterhead Lettuce to Simultaneously Enhance Polyphenols and Antioxidant Activity. Chemom. Intell. Lab. Syst. 2015, 146, 47-54. [CrossRef]

47. Ogbole, O.O.; Segun, P.A.; Adeniji, A.J. In Vitro Cytotoxic Activity of Medicinal Plants from Nigeria Ethnomedicine on Rhabdomyosarcoma Cancer Cell Line and HPLC Analysis of Active Extracts. BMC Complementary Altern. Med. 2017, 17, 494. [CrossRef] [PubMed]

48. Mousinho, N.M.H.D.C.; van Tonder, J.J.; Steenkamp, V. In Vitro Anti-Diabetic Activity of Sclerocarya Birrea and Ziziphus Mucronata. Nat. Prod. Commun. 2013, 8, 1279-1284. [PubMed]

49. Chaves, J.O.; de Souza, M.C.; da Silva, L.C.; Lachos-Perez, D.; Torres-Mayanga, P.C.; da Fonseca Machado, A.P.; Forster-Carneiro, T.; Vázquez-Espinosa, M.; González-de-Peredo, A.V.; Barbero, G.F.; et al. Extraction of Flavonoids from Natural Sources Using Modern Techniques. Front. Chem. 2020, 8, 8. [CrossRef]

50. Zhang, J.; Yuan, K.; Zhou, W.; Zhou, J.; Yang, P. Studies on the Active Components and Antioxidant Activities of the Extracts of Mimosa Pudica Linn. from Southern China. Pharmacogn. Mag. 2011, 7, 35-39.

51. Zhang, H.-F.; Yang, X.-H.; Wang, Y. Microwave Assisted Extraction of Secondary Metabolites from Plants: Current Status and Future Directions. Trends Food Sci. Technol. 2011, 22, 672-688. [CrossRef]

52. Sedraoui, S.; Badr, A.; Barba, M.G.M.; Doyen, A.; Tabka, Z.; Desjardins, Y. Optimization of the Ultrahigh-Pressure-Assisted Extraction of Phenolic Compounds and Antioxidant Activity from Palm Dates (Phoenix dactylifera L.). Food Anal. Methods 2020, 13, 1556-1569. [CrossRef]

53. Jagetia, G.C.; Vanlalhruaii, F. Anticancer Potential of Mimosa Pudica Linn. Lajwanti in Cultured Dalton's Ascites Lymphoma Cells. Int. J. Complementary Altern. Med. 2020, 13, 91-94.

54. Satoh, T. Molecular Mechanisms for the Regulation of Insulin-Stimulated Glucose Uptake by Small Guanosine Triphosphatases in Skeletal Muscle and Adipocytes. Int. J. Mol. Sci. 2014, 15, 18677-18692. [CrossRef] [PubMed]

55. Sunday, R.M.; Obuotor, E.M.; Kumar, A. Antioxidant and Antidiabetic Properties of Mimosa Pudica Seeds in StreptozotocinInduced Diabetic Wistar Rats. Asian J. Biotechnol. 2019, 12, 1-8. [CrossRef]

56. Parasuraman, S.; Ching, T.H.; Leong, C.H.; Banik, U. Antidiabetic and Antihyperlipidemic Effects of a Methanolic Extract of Mimosa Pudica (Fabaceae) in Diabetic Rats. Egypt. J. Basic Appl. Sci. 2019, 6, 137-148. [CrossRef]

57. Rajendiran, D.; Khan, H.B.H.; Packirisamy, S.; Gunasekaran, K. Dose Dependent Antidiabetic Effect of Mimosa Pudica Leaves Extract in Type 2 Diabetic Rat Model. Pharma Innov. J. 2019, 8, 1-4.

58. Yupparach, P.; Konsue, A. Hypoglycemic and Hypolipidemic Activities of Ethanolic Extract from Mimosa pudica L. in Normal and Streptozotocin-Induced Diabetic Rats. Pharmacogn. J. 2017, 9, 834-837. [CrossRef]

59. Ha, D.T.; Nam Trung, T.; Bich Thu, N.; Van On, T.; Hai Nam, N.; Van Men, C.; Thi Phuong, T.; Bae, K. Adlay Seed Extract (Coix Lachryma-Jobi L.) Decreased Adipocyte Differentiation and Increased Glucose Uptake in 3T3-L1 Cells. J. Med. Food 2010, 13, 1331-1339. [CrossRef] [PubMed] 